\title{
Neighbouring rights for publishers: are national and (possible) EU initiatives lawful?
}

by Eleonora Rosati*

\begin{abstract}
$\underline{\text { Abstract }}$
To tackle the financial difficulties facing the newspaper industry, different solutions have been advanced in Europe. These have resulted in either the conclusion of consensual agreements or the adoption of national legislative initiatives to create sui generis rights over news content. Currently also the EU Commission is considering whether a neighbouring right for publishers - whether in the press sector alone or also other sectors - should be proposed for adoption at the EU level.
\end{abstract}

This contribution discusses: (1) the compatibility with EU law of national legislative initiatives that have resulted in the creation of sui generis rights for press publishers; and (2) whether a neighbouring right for publishers may be adopted at the EU level and, if so, what changes of the copyright acquis are required. It concludes that, while the former may be contrary to Member States' obligations under EU law, the latter may be pursued by amending relevant directives.

Keywords: ancillary copyright, ancillary rights, copyright, Digital Single Market Strategy, Directive 2001/29, Directive 2006/115, EU Commission, neighbouring rights, news aggregators

\section{$\underline{\text { Introduction }}$}

Over the past few years debate has ensued at the level of EU Member States and the EU alike on how to address declining revenues in the press publishing sector. Although this is not a new phenomenon (in some European countries newspaper circulation has been in decline since the 1950s, in parallel with the advent of television), since 2000 newspaper advertising sales in Europe have fallen across the board. ${ }^{1}$ This data is in line with what has also occurred

\footnotetext{
*PhD (EUI), LLM (Cantab), Laurea (Florence). Avvocato (Italian-qualified lawyer) and lecturer in Intellectual Property Law, University of Southampton. Email: eleonora@e-lawnora.com. Twitter: @eLAWnora. I am grateful to Cédric Manara (Google) and Lionel Bently (University of Cambridge) for their comments on an earlier draft, as well as the anonymous peer-reviewers of the International Review of Intellectual Property and Competition Law. Errors and omissions remain my own.

${ }^{1}$ Price (2015), 3.
} 
in the US where, according to the Pew Research Center, from 2013 to 2014 newspapers' annual overall revenues have fallen from approximately $\$ 46 \mathrm{~m}$ to approximately $\$ 20 \mathrm{~m} .^{2}$

Some have indicated the internet, notably news aggregation services (ie aggregators of syndicated web content in one location, an example being Google News), as primarily responsible for this phenomenon. According to two studies by the lowa University ${ }^{3}$ and ETH and Boston University ${ }^{4}$ respectively, not only are news aggregators unlikely to have complementary effects on the number of visits received by newspapers' homepages, but rather appear to have a substitution effect, which is said to have contributed to declining online traffic. ${ }^{5}$

Possible solutions to tackle this phenomenon have been discussed in a number of EU Member States. These have resulted in either the conclusion of agreements between Google and local press publishers (Belgium, France, Italy) or the adoption of legislative initiatives in relation to news content (Germany, Spain). Currently also the EU Commission is considering whether a neighbouring right for publishers (come to be known as 'ancillary copyright') whether in the press sector alone or also other sectors - should be proposed for adoption at the EU level.

This contribution discusses: (1) the compatibility with EU law of national legislative initiatives (Germany and Spain) that have resulted in the creation of sui generis rights for press publishers, and (2) whether a neighbouring right for publishers may be adopted at the EU level and, if so, what changes of the copyright acquis are required to this end. The present work does not discuss the merits of introducing a neighbouring right for publishers as such, but solely its legal feasibility.

Following an overview of recent national developments and legislative initiatives in the press sector and current discussion at the EU level, the analysis will consist of two parts. The first part will focus on the compatibility of national rights for press publishers with the current acquis in the area of copyright - notably Directive $2001 / 29^{6}$ (the InfoSoc Directive) and Directive 2006/115 (the Rental and Lending Rights Directive). By considering relevant case law of the Court of Justice of the European Union (CJEU), it will recall that the InfoSoc Directive intended to achieve a broad harmonisation of national copyright laws. In Svensson $v$ Retriever $^{8}$ (Svensson) the CJEU clarified that, by adopting the InfoSoc Directive, the EU

\footnotetext{
2 Barthel (29 April 2015).

${ }^{3}$ Madsen and Andsager (2012).

${ }^{4}$ Calin and Others (2013).

${ }^{5}$ See contra Chiou and Tucker (2015); Comisión Nacional de los Mercados y la Competencia (16 May 2014) (CNMC), §III.1.

${ }^{6}$ Directive 2001/29/EC of the European Parliament and of the Council of 22 May 2001 on the harmonisation of certain aspects of copyright and neighbouring rights in the information society, OJ L 167, 10-19.

${ }^{7}$ Directive 2006/115 of the European Parliament and of the Council of 12 December 2006 on rental and lending right and on certain rights neighbouring to copyright in the field of intellectual property (codified version), OJ L 376, 28-35.

${ }^{8}$ Nils Svensson and Others v Retriever Sverige AB, C-466/12, EU:C:2014:76.
} 
legislature deprived Member States of the freedom to broaden the scope of relevant economic rights. In Hewlett-Packard Belgium v Reprobel ${ }^{9}$ (Reprobel) the CJEU held that the term 'rightholders' in the InfoSoc Directive does not include 'publishers'. From a combined reading of Svensson and Reprobel, it follows that publishers cannot be granted any rights under the InfoSoc Directive. This is not only true in the copyright area, but also in relation to neighbouring rights. While C More Entertainment v Sandberg ${ }^{10}$ (C More) suggests that Member States can broaden the scope of the neighbouring rights harmonised in the Rental and Lending Rights Directive (including in relation to communication to the public), this decision does not also suggest that Member States are free to add new categories of rightholders in addition to those indicated in that directive.

The second part will consider the possibility of adopting a neighbouring right for publishers at the EU level. In particular it suggests that to this end the wording of both the InfoSoc Directive and Rental and Lending Rights Directive should be amended. In relation to the InfoSoc Directive, this part also considers Article 5(3)(d) of the InfoSoc Directive in light of Article 10(1) of the Berne Convention and the apparent mandatory nature of the exception or limitation for quotation. It considers the CJEU decision in Painer v Standard VerlagsGmbH ${ }^{11}$ (Painer), and concludes that, even assuming that the InfoSoc Directive is incompatible with the Berne Convention in respect of Article 10(1) thereof, the exception or limitation for quotation would not cover the reproduction (and possible subsequent communication/making available to the public and distribution) of extracts of third-party works or other subject-matter protected by neighbouring rights where such reproduction is not also accompanied by commentary or criticism.

The contribution concludes that, while national initiatives that have resulted in the adoption of sui generis rights for press publishers are likely incompatible with EU law, a similar initiative at the EU level might be feasible and achieved by amending the InfoSoc Directive and the Rental and Lending Rights Directive.

\section{National initiatives}

Over the past few years various solutions have been identified to recoup some of the revenues that press publishers have allegedly lost due to the digitisation of content and neighbouring distribution channels. ${ }^{12}$ These have mainly resulted in either the conclusion of agreements between interested parties (press publishers and Google) or the adoption of legislative initiatives that have introduced sui generis rights for press publishers in their news content. ${ }^{13}$ A debate similar to the one undertaken at the level of individual Member States is currently ongoing at the EU level, where the Commission is considering whether to propose

\footnotetext{
${ }^{9}$ Hewlett-Packard Belgium SPRL v Reprobel SCRL, C-572/13, EU:C:2015:750.

${ }^{10}$ C More Entertainment AB v Linus Sandberg, C-279/13, EU:C:2015:199.

${ }^{11}$ Eva-Maria Painer v Standard VerlagsGmbH and Others, C-145/10, EU:C:2011:798.

12 Barabash (2013), 244.

${ }^{13}$ On the latter see Scalzini (2015), 461-463.
} 
the adoption of an EU-wide right for publishers, whether in the press sector alone or also in other fields (see further below, sub §3.1.).

\subsection{Consensual solutions}

In 2012 a number of leading French newspaper publishers called on François Hollande's Government to adopt a law to force internet search engines like Google to pay for displaying their content on services such as Google News. Later that year, in an interview with Italian newspaper Corriere della Sera, the then Minister of Culture Aurélie Filippetti revealed that the Government would indeed adopt a law requiring Google to pay royalties on the contents displayed on its News service should this and the publishers fail to conclude an agreement before the end of 2012. ${ }^{14}$ Such an agreement was indeed concluded in early 2013. It excluded that Google would have to obtain a licence to display snippets of and links to news publishers' content, but in return Google would create a EUR 60m Digital Publishing Innovation Fund to support transformative French digital publishing initiatives. In addition Google would build on its previous commitments in France (eg the Google Cultural Institute in Paris), and deepen its partnership with French publishers to help increase their online revenue using Google advertising technology at a reduced cost. ${ }^{15}$

The agreement in France between Google and local press publishers followed another agreement previously concluded (late 2012) by Google with French-language press publishers in Belgium. The Belgian agreement would consent to partner on a broad range of business initiatives, in order to: promote both the publishers' and Google's services by means of advertising solutions; increase publishers' revenues via premium models (eg paywalls, subscriptions) and advertising solutions (eg AdSense, AdExchange) alike; increase reader engagement by implementing Google+ social tools, including video Hangouts, on news sites, and launching official YouTube channels; and increase the accessibility of the publishers' content by collaborating on the distribution of publishers' original content on mobile platforms, in particular smartphones and tablets. ${ }^{16}$

Further to the initiatives in Belgium and France, in mid-2016 Google also concluded a similar agreement with press publishers of the Federazione Italiana Editori Giornale (FIEG) in Italy. ${ }^{17}$ Among other things, the agreement envisages an investment by Google of EUR12m over a three-year period and foresees that FIEG members will be granted the possibility to: distribute their content on mobile devices via Google Play Newsstand; use Google Analytics tools; develop a new video strategy via YouTube; collaborate with Google to protect online

\footnotetext{
${ }^{14}$ Rosati (24 November 2012)

${ }^{15}$ Schmidt (1 February 2013).

${ }^{16}$ Geerts (12 December 2012).

${ }^{17}$ La Stampa (7 June 2016).
} 
content; safeguard their rights via tools made available by Google; and participate in the creation of a Digital Lab@Fieg, to transfer and share know-how. ${ }^{18}$

\subsection{Legislative initiatives}

Backed by Chancellor Angela Merkel's ruling coalition, in 2013 the German Bundesrat approved a piece of legislation that provides press publishers with an sui generis right over their news content. The newly created sections 87f, 87g and 87h of the Urheberrechtsgesetz (German Copyright Act) provide for the exclusive right of press publishers to exploit their contents commercially for one year, thus preventing third parties (including search engines and news aggregators) from displaying excerpts from newspaper articles without obtaining a licence. Shortly prior to its adoption, the text of the bill was amended to the effect that contrary to the original proposal - no licence would be needed to display single words or short-text snippets. However, the text approved by the German parliament does not clarify the length required to fall within such exemption.

As previously announced by Google ${ }^{19}$, the very day on which the new provisions of the German Copyright Act entered into force Google News became opt-in. This means that only the sources of those who ask to be included in Google's news aggregation service would be indexed. This would remove the obligation for Google to obtain a licence (and pay the relevant licence fee) from relevant rightholders. Major publishers, including those of popular newspaper Der Spiegel, announced that they would opt-in Google's news aggregation service. ${ }^{20}$ Despite a complaint in 2013 by collecting society VG Media that Google's conduct in connection with the introduction of the German right for press publishers would be contrary to competition law, the German Competition Authority (Bundeskartellamt) decided not to open formal proceedings against Google. ${ }^{21}$

In 2014 the Spanish Parliament adopted a law (which entered into force on 1 January 2015) aimed at undertaking a major reform of Spanish intellectual property regime. Among other things, this reformed the quotation exception within Article 32 of the Ley de Propiedad Intelectual (Intellectual Property Law). Despite relying on a mechanism (that of copyright exceptions) different from the one envisaged under German law, Article 32 as reformed has introduced a right to 'equitable remuneration' that, in its substance, is not dissimilar from the German press publishers' right. There is however a significant difference, ie that - unlike the German right - the Spanish 'right' cannot be waived.

Shortly prior to the entry into force of the Spanish reform, Google announced that on 1 January 2015 it would stop providing its News service in this country. This was motivated on grounds that "[t]his new legislation requires every Spanish publication to charge services like

\footnotetext{
${ }^{18}$ ANSA (7 June 2016).

${ }^{19}$ Rabenstei (21 June 2013).

20 Lardinois (21 June 2013).

${ }^{21}$ Bundeskartellamt (9 September 2015).
} 
Google News for showing even the smallest snippet from their publications, whether they want to or not. As Google News itself makes no money ... this new approach is simply not sustainable."22

\section{The scope of EU law and the freedom of Member States}

\subsection{The objectives of the InfoSoc Directive}

By adopting the InfoSoc Directive, the EU intended to achieve two main objectives. The first one was to align EU copyright law with and implement into EU legal order the WIPO Internet Treaties. ${ }^{23}$ The second objective was to harmonise certain aspects of substantive copyright law, in line with the agenda that the Commission had set in its 1995 Green Paper $^{24}$ and 1996 Follow-up. ${ }^{25}$ These had somewhat marked a departure from earlier policy of piecemeal approximation. ${ }^{26}$ Overall, it was felt that, without harmonisation at the (then) Community level, national legislative initiatives would result in significant differences in protection and thereby in restrictions on the free movement of services and products incorporating or based on copyright. ${ }^{27}$ In particular, diverging approaches at the national level with regard to both copyright and neighbouring rights would cause legal uncertainties and lead to a refragmentation of the internal market. ${ }^{28}$ Ultimately, the impact of legislative differences and uncertainties between Member States would hinder economies of scale for new products and services. ${ }^{29}$ Hence, not only should the EU harmonise certain aspects of copyright and neighbouring rights, but also inconsistent national legislative responses to technological developments should be avoided. ${ }^{30}$ This would be also necessary "to ensure that competition in the internal market is not distorted as a result of differences in the legislation of Member States." 31

With specific regard to the right of communication to the public (which is particularly relevant to the discussion around aggregation of news content and subsequent display of relevant links and snippets), Recital 23 in the preamble to the InfoSoc Directive clarifies, on

\footnotetext{
22 Gingras (11 December 2014).

23 InfoSoc Directive, Recital 15.

${ }^{24}$ Commission of the European Communities, Green Paper on Copyright and Neighbouring Rights in the Information Society, $\operatorname{COM}(95) 382$ final.

${ }^{25}$ Commission of the European Communities, Communication from the Commission: Follow-Up to the Green Paper on Copyright and Neighbouring Rights in the Information Society, COM(96) 568 final.

${ }^{26}$ Hugenholtz,(2000), 500.

27 InfoSoc Directive, Recital 6.

28 /bid, Recital 7.

${ }^{29}$ Ibid, Recital 6.

30 Ibid, Recital 7.

${ }^{31}$ DR and TV2 Danmark A/S v NCB - Nordisk Copyright Bureau, C-510/10, EU:C:2012:244, [35], referring to Laserdisken ApS v Kulturministeriet, C-479/04, EU:C:2006:549, [26] and [31]-[34].
} 
the one hand, how this right "should be understood in a broad sense" and, on the other hand (and similarly to the making available right) ${ }^{32}$, "should not cover any other acts" beyond the acts referred to in this directive. With specific regard to acts of online on-demand transmission of copyright works and subject-matter protected by neighbouring rights, Recital 25 further stresses how the legal uncertainty regarding the nature and the level of protection should be overcome by providing for harmonised protection at the EU level.

\subsection{The scope of harmonised rights}

Following the adoption of the InfoSoc Directive, it has been uncertain to what extent Member States remain free to legislate autonomously, both in respect of the rights harmonised therein and their neighbouring exceptions and limitations. As also argued in an earlier work ${ }^{33}$, from recent CJEU case law it has become apparent that the InfoSoc Directive should be interpreted as leaving very limited (if any at all) room for independent national initiatives. This has been so - among other things - in relation to the exclusive rights harmonised by this directive, including the right of communication to the public within Article 3(1) of the InfoSoc Directive. This provision states that:

"Member States shall provide authors with the exclusive right to authorise or prohibit any communication to the public of their works, by wire or wireless means, including the making available to the public of their works in such a way that members of the public may access them from a place and at a time individually chosen by them."

This right is particularly relevant to the present discussion, in that the ad hoc right over news content as adopted in Germany and - as a matter of fact - Spain has arguably: (1) created a new category of initial rightholders, ie publishers, a category not expressly envisaged by the InfoSoc Directive; and has thus (2) broadened the scope of the right of communication to the public, by allowing them to control - and prevent - the unauthorised provision of links to and small excerpts of relevant news content.

\subsubsection{The CJEU decision in Svensson}

In its decision in Svensson the CJEU notoriously addressed the issue whether providing a clickable link to a work lawfully made available on a certain website where it is freely accessible falls within the scope of Article 3(1) of the InfoSoc Directive. This was a reference for a preliminary ruling from the Svea Court of Appeal (Sweden) made in the context of proceedings between a number of journalists and Retriever Sverige concerning compensation allegedly payable to them for the harm suffered as a result of the inclusion on that company's website of hyperlinks redirecting users to press articles (in which the applicants held the copyright) and freely accessible on the Göteborgs-Posten website.

The CJEU noted at the outset that the concept of communication to the public includes two cumulative criteria: an 'act of communication' of a work and the communication of that work

\footnotetext{
32 InfoSoc Directive, Recital 24.

33 Rosati (2014).
} 
to a 'public'. ${ }^{34}$ As regards the first criterion, this must be construed broadly in order to ensure, in accordance with - among other things - Recitals 4, 9 and 23 in the preamble to the InfoSoc Directive, a high level of protection for copyright holders. ${ }^{35}$ The CJEU concluded that the provision, on a website, of clickable links to protected works published without any access restrictions on another site, affords users of the first site direct access to those works ${ }^{36}$, and therefore amounts to an 'act of communication'. ${ }^{37}$ Turning to the second criterion, ie that the communication of the work in question is to a 'public', the CJEU recalled that this term refers to an indeterminate number of potential recipients and implies fairly large number of persons. ${ }^{38}$ However, an act of communication within Article 3(1) of the InfoSoc Directive requires that a communication concerning the same works as those covered by the initial communication and made by the same technical means (ie internet), must also be directed at a 'new' public. According to the CJEU this is "a public that was not taken into account by the copyright holders when they authorised the initial communication to the public". ${ }^{39}$ The provision of a clickable link to a work (lawfully and) freely accessible on a third-party website does not fall within the scope of Article 3(1) of the InfoSoc Directive. ${ }^{40}$ This is because the public targeted by the initial communication consists of all potential visitors to the site concerned. ${ }^{41}$ As such, the link would not communicate the work to a public not taken into account at the time of authorising the initial communication. ${ }^{42}$

The CJEU confirmed the approach taken in Svensson in the subsequent order in BestWater International $v$ Mebes and Potsch. ${ }^{43}$ Although acknowledging that the right of communication within Article 3(1) of the InfoSoc Directive must be construed broadly and despite the uncertainties surrounding linking to unlicensed content (this is currently the issue under consideration in GS Media $v$ Sanoma ${ }^{44}$ ), the CJEU indicated that the provision of a link to content that is freely accessible on a third-party website does not fall within the scope of this provision.

\footnotetext{
${ }^{34}$ Nils Svensson and Others $v$ Retriever Sverige AB, cit, [16], referring to ITV Broadcasting Ltd and Others v TV Catch Up Ltd, C-607/11, EU:C:2013:147, [21] and [31].

35 Ibid, [17]. On this point see also - more recently - OSA - Ochranný svaz autorský pro práva k dillúm hudebním os v Léčebné lázně Mariánské Lázně as, C-351/12, EU:C:2014:110, [23]; Sociedade Portuguesa de Autores CRL v Ministério Público and Others, C-151/15, EU:C:2015:468, [12]; SBS Belgium NV v Belgische Vereniging van Auteurs, Componisten en Uitgevers (SABAM), C-325/14, EU:C:2015:764, [14].

${ }^{36}$ Nils Svensson and Others v Retriever Sverige AB, cit,, [18].

37 Ibid, [20].

38 Ibid, [21], referring to Sociedad General de Autores y Editores de España (SGAE) v Rafael Hoteles SA, C-306/05, EU:C:2006:764, [37]-[38], and ITV Broadcasting Ltd and Others V TV Catch Up Ltd, cit, [32].

39 Ibid, [24], referring by analogy to Sociedad General de Autores y Editores de España (SGAE) v Rafael Hoteles SA, cit, [40] and [42]; Organismos Sillogikis Diacheirisis Dimiourgon Theatrikon kai Optikoakoustikon Ergon, C-136/09, EU:C:2010:151, [38]; and ITV Broadcasting Ltd and Others v TV Catch Up Ltd, cit, [39].

40 Ibid, [25].

41 Ibid, [26].

42 Ibid, [27].

${ }^{43}$ BestWater International GmbH v Michael Mebes and Stefan Potsch, C-348/13, EU:C:2014:2315.

${ }^{44}$ GS Media BV v Sanoma Media Netherlands BV, Playboy Enterprises International Inc and Britt Geertruida Dekker, C-160/15 (in progress).
} 
In Svensson the CJEU did not only address the issue of whether the provision of clickable links is to be regarded as an act of communication to the public. Among the questions referred by the Swedish court there was also whether Article 3(1) of the InfoSoc Directive precludes a Member State from granting broader protection to copyright holders by laying down that the concept of communication to the public includes a wider range of activities than those referred to in that provision. The CJEU answered this question in the affirmative. It noted at the outset how Recitals 1, 6 and 7 in the preamble to the InfoSoc Directive clarify that by adopting this piece of legislation the EU intended to remove the legislative differences and legal uncertainty facing the scope of copyright protection. Accordingly,

"Acceptance of the proposition that a Member State may give wider protection to copyright holders by laying down that the concept of communication to the public also includes activities other than those referred to in Article 3(1) of Directive 2001/29 would have the effect of creating legislative differences and thus, for third parties, legal uncertainty." 45

The Court continued that "the objective pursued by Directive 2001/29 would inevitably be undermined if the concept of communication to the public were to be construed in different Member States as including a wider range of activities than those referred to in Article 3(1) of that directive." 46 It conceded that Recital 7 (which refers to both copyright and neighbouring rights) clarifies that the directive does not intend to remove or prevent differences that do not adversely affect the functioning of the internal market. ${ }^{47}$ However,

"if the Member States were to be afforded the possibility of laying down that the concept of communication to the public includes a wider range of activities than those referred to in Article 3(1) of the directive, the functioning of the internal market would be bound to be adversely affected." ${ }^{\prime 8}$ (emphasis added)

In light of the Svensson decision Member States are precluded the possibility of extending the scope of the right of communication to the public, but also - by analogy - the other rights (reproduction, making available to the public, and distribution) harmonised by this piece of EU legislation. Importantly, in its decision the CJEU appeared to set a far-reaching prohibition: Member States are prevented from broadening the scope of "the concept of communication to the public" as such, not just in the context of national implementations of Article 3(1) of the InfoSoc Directive. Also on consideration of the fact that the InfoSoc Directive intended to harmonise copyright and neighbouring rights alike ${ }^{49}$, and precluded - in relation to both - "inconsistent national responses to the technological developments" 50 , it follows that the prohibition laid down in Svensson should be read as addressed at both

\footnotetext{
${ }^{45}$ Nils Svensson and Others $v$ Retriever Sverige AB, cit, [34].

46 Ibid, [35].

47 Ibid, [36].

48 Ibid.

49 InfoSoc Directive, particularly Recitals 1 and 7.

50 lbid, Recital 7.
} 
copyright and neighbouring rights (the latter - however and as will be discussed further below - subject to the qualification provided in $\mathrm{CMore)}$.

\subsubsection{The freedom of Member States in relation to neighbouring rights is limited to the acts covered, not rightholders: CMore}

In the later C More case the CJEU addressed the issue of whether Member States are precluded from granting holders of the making available right pursuant to Article 3(2)(d) of the InfoSoc Directive (in that case, broadcasting organisations) an exclusive right as regards acts which could be classified as acts of communication to the public but which do not constitute acts of making available to the public.

Article 3(2)(d) of the InfoSoc Directive provides that:

"Member States shall provide for the exclusive right to authorise or prohibit the making available to the public, by wire or wireless means, in such a way that members of the public may access them from a place and at a time individually chosen by them ... for broadcasting organisations, of fixations of their broadcasts, whether these broadcasts are transmitted by wire or over the air, including by cable or satellite."

CMore was a reference for a preliminary ruling from the Swedish Supreme Court. It was made in the context of proceedings between C More, a pay-TV station which also broadcasts live on its internet site (for payment of a fee) ice hockey matches, and Linus Sandberg. The latter had made available on his website hyperlinks enabling users to circumvent the paywall put in place by C More and watch live two ice hockey matches. Sandberg was prosecuted before the Hudiksvall District Court, which found him liable of copyright infringement. Both parties appealed before the Nerdre Norrland Court of Appeal. This court found that no part of the commentators', cameramen's or picture producers' work on the broadcasts of the ice hockey matches, taken on its own merits or some or all of those parts taken together, reached the level of originality required for copyright protection under Swedish copyright law. Nonetheless, the Court of Appeal held that, not copyright, but rather C More's neighbouring rights in the broadcasts had been infringed. C More appealed this decision before the Supreme Court, seeking a declaration that it was the holder of copyright and to have the amount of damages due reviewed and increased.

Besides the issue of whether the provision of hyperlinks on an internet site constitutes an act of communication to the public (in the view of the court this would not be the case), the Supreme Court noted that Swedish law provides for wider neighbouring rights than those set out in Article 3(2) of the InfoSoc Directive: unlike that provision, the protection conferred by Swedish law is not restricted to acts of making works available 'on demand'. The Supreme Court sought guidance from the CJEU on a number of issues. However, following the CJEU decision in Svensson (which was rendered after the reference in CMore was made), the Supreme Court withdrew all its question, with the exception of the one asking whether Member States are entitled to give broader protection to the exclusive right of authors by enabling 'communication to the public' to cover a greater range of acts than provided for in Article 3(2) of the InfoSoc Directive. 
In its analysis the CJEU first considered whether live broadcasts transmitted online could be regarded as an act of making available to the public. The Court answered in the negative, noting that for an act to fall within Article 3(2) of the InfoSoc Directive two cumulative conditions must be satisfied, ie that members of the public may access the protected work from a place and at a time individually chosen by them. ${ }^{51}$ The latter would not be the case of live streams. ${ }^{52}$

The Court then considered whether Member States are entitled to grant the broadcasting organisations referred to in Article 3(2)(d) of the InfoSoc Directive an exclusive right as regards acts which could be classified as acts of communication to the public but which do not constitute acts of making available to the public within the meaning of that provision. The CJEU noted that the InfoSoc Directive has only harmonised copyright and neighbouring rights in part. ${ }^{53}$ Although it is true that by adopting the InfoSoc Directive the EU legislature sought to harmonise further the right of communication to the public and overcome the legal uncertainty regarding the nature and the level of protection of acts of on-demand transmission ${ }^{54}$, the InfoSoc Directive did not seek "to harmonise and, in consequence, prevent or remove any differences between the national legislations as regards the extent of the protection which the Member States may grant to the holders of the rights referred to in Article $3(2)(d)$ with regard to certain acts ... which are not expressly referred to in that provision." 55

This said, the CJEU recalled that Recital 16 in the preamble to the Rental and Lending Rights Directive provides Member States with some freedom, ie "to provide for more far-reaching protection for owners of rights neighbouring to copyright than that required by the provisions laid down in this Directive in respect of broadcasting and communication to the public." ${ }^{56}$ Article 8 of the Rental and Lending Rights Directive has achieved a de minimis harmonisation ${ }^{57}$ for a number of righthholders, ie: performers in relation to their performances, phonogram producers and performers in relation to phonograms; and broadcasting organisations in relation to their broadcasts. According to the CJEU it is possible for Member States to provide for more protective provisions with regard to the broadcasting and communication to the public of transmissions made by broadcasting organisations than those which must be instituted in accordance with Article 8(3) of the Rental and Lending Rights Directive. ${ }^{58}$ However, such measures must not affect the protection of copyright in any way. ${ }^{59}$

\footnotetext{
${ }^{51}$ C More Entertainment AB v Linus Sandberg, cit, [25].

52 Ibid, [27].

${ }^{53}$ Ibid, [29].

${ }^{54} \mathrm{Ibid}$, [30].

55 Ibid, [31].

${ }^{56} \mathrm{Ibid},[33]$.

${ }^{57}$ In this sense, Lewinski (2010), §6.8.2.

${ }^{58}$ C More Entertainment AB v Linus Sandberg, cit,, [35].

59 lbid.
} 
While C More supports the view that the categories of acts covered by neighbouring rights can be broadened at the national level, it does not also suggest that Member States are free to create new categories of rightholders for such neighbouring rights. As it would be discussed further below, holding otherwise would raise the question whether the creation of new neighbouring rights or the extension of harmonised neighbouring rights to new categories of rightholders contravenes the wording of Recital 17 in the preamble to the Rental and Lending Rights Directive. This recital warns against the exercise of neighbouring rights in a way that constitutes a disguised restriction on trade between Member States.

Recently, the CJEU has held the view that the notion of 'rightholders' under EU directives, including the InfoSoc Directive, is not a generic term, but rather an umbrella term that includes only the specific types of rightholders indicated thereof.

\subsection{New categories of rightholders are prohibited by the InfoSoc Directive: the Reprobel decision}

The one outlined above in relation to the scope of 'communication to the public' is not the only problem of compatibility with the InfoSoc Directive of national rights for press publishers. By envisaging an ad hoc right over news content, national legislatures in Germany and Spain have indicated press publishers as the relevant rightholders. Publishers are not included in the InfoSoc Directive among relevant rightholders, and the question that arises is whether the creation of this new category of rightholders may be compliant with this directive. The answer appears to be in the negative. This follows from the recent CJEU decision in Reprobel.

This reference for a preliminary ruling from Brussels Court of Appeal (Belgium) originated in the context of litigation between Hewlett-Packard (HP) and Belgian collective management rights organisation Reprobel. In 2004 the latter informed HP that the sale of multifunction devices entailed payment of a levy of EUR 49.20 per printer, and this should apply retrospectively. In 2010 HP summoned Reprobel before the Brussel Court of First Instance, seeking a declaration that no remuneration was owed for the printers which it had offered for sale, or, in the alternative, that the remuneration which it had paid corresponded to the fair compensation owed pursuant to the Belgian legislation, interpreted in the light of the InfoSoc Directive. Following complex litigation which also entailed a discussion of the alleged incompatibility of Belgian law with EU law, the Brussels Court of Appeal decided to stay the proceedings and seek guidance from the CJEU regarding several issues. Among the questions referred there was whether Member States can allocate part of the fair compensation within Articles 5(2)(a) (reprography) and 5(2)(b) (private copying) of the InfoSoc Directive to the publishers of works created by authors.

Article 5(2)(a) of the InfoSoc Directive states that:

"Member States may provide for exceptions or limitations to the reproduction right provided for in Article 2 in ... in respect of reproductions on paper or any similar medium, effected by the use of any kind of photographic technique or by some other process having similar effects, with the exception of sheet music, provided that the rightholders receive fair compensation". 
In a similar fashion, Article 5(2)(b) provides that:

"Member States may provide for exceptions or limitations to the reproduction right provided for in Article 2 in ... respect of reproductions on any medium made by a natural person for private use and for ends that are neither directly nor indirectly commercial, on condition that the rightholders receive fair compensation which takes account of the application or non-application of technological measures referred to in Article 6 to the work or subject-matter concerned".

In his Opinion Advocate General (AG) Cruz Villalón held the view that publishers as such cannot be the beneficiaries of the fair compensation. ${ }^{60}$ The $A G$ achieved this conclusion by means of a systematic interpretation of the InfoSoc Directive. He noted at the outset that Article 2(a) thereof lays down, for authors only, the exclusive right to authorise or prohibit direct or indirect, temporary or permanent reproduction by any means and in any form, in whole or in part, of their works. ${ }^{61}$ As such, publishers are not included among the holders of the exclusive right of reproduction protected by the InfoSoc Directive. This is unlike, for example, phonogram producers or producers of the first fixations of films, referred to respectively in Article 2(c) and (d) of that directive. For them the investment required to produce products such as phonograms, films or multimedia products is deemed to be considerable and therefore capable of justifying adequate legal protection. ${ }^{62}$ The AG added that - in a similar fashion - Article 4 of the InfoSoc Directive only provides for authors, in respect of the original of their works or of copies thereof, the exclusive right to authorise or prohibit any form of distribution to the public by sale or otherwise. ${ }^{63}$

The AG also referred to the earlier CJEU decision in Amazon.com v Austro-Mechana ${ }^{64}$ (Amazon.com). ${ }^{65}$ In that case the Court held that the InfoSoc Directive does not oblige the Member States to pay rightholders or their legal successors all the fair compensation in cash, nor does it preclude them from providing, in the exercise of the wide discretion which they enjoy, that part of that compensation be made in the form of indirect compensation, through the intermediary of social and cultural establishments set up for their benefit, provided, however, that those establishments actually benefit them and that the detailed arrangements for their operation are not discriminatory. According to the AG, publishers "can in no way be equated with social and cultural establishments set up for the benefit of authors" ${ }^{66}$ The AG conceded that the InfoSoc Directive only harmonised certain aspects of copyright and neighbouring rights, and does not contain any provision precluding the right of

\footnotetext{
60 Opinion of Advocate General Pedro Cruz Villalón in Hewlett-Packard Belgium SPRL v Reprobel SCRL, C-572/13, EU:C:2015:389, [127].

61 Ibid, [124].

62 Ibid, [125].

63 Ibid, [126].

${ }^{64}$ Amazon.com International Sales Inc. and Others v Austro-Mechana Gesellschaft zur Wahrnehmung mechanisch-musikalischer Urheberrechte Gesellschaft mbH, C-521/11, EU:C:2013:515, [49]-[50] and [53].

65 Opinion of Advocate General Pedro Cruz Villalón in Hewlett-Packard Belgium SPRL v Reprobel SCRL, cit, [128].

66 Ibid, [130].
} 
Member States to establish remuneration specifically for publishers, but this should be limited to the objective of compensating for the harm suffered by the latter as a result of the marketing and use of reprography equipment and devices. ${ }^{67}$

Following the AG Opinion and prior to the CJEU decision, the European Copyright Society (ECS) issued an Opinion ${ }^{68}$ in which it advised the Court to uphold the conclusions of the AG on this point. The ECS held the view that the author principle, ie that rights comprised within copyright should first belong to the individual creators, is rooted - among other things within Articles 2 to 4 of the InfoSoc Directive. ${ }^{69}$ Further to the ECS Opinion, the International Federation of Reproduction Rights Organisations (IFRRO) released a document, in which among other things and similarly to the position later adopted by a group of umbrella organisations in the publishing sector ${ }^{70}$ - it held the view that the InfoSoc Directive "uncontestedly, referred to 'rightholder' as a generic term for authors and publishers". ${ }^{71}$ As such it advised the CJEU to depart from the views expressed by AG Cruz Villalón and the ECS and uphold instead Belgian legislation that $a b$ initio reserved part of the fair compensation for reprography and private copying to publishers.

In its decision in late 2015, the CJEU confirmed the AG analysis. The Court noted at the outset that publishers are not among the reproduction rightholders listed in Article 2 of the InfoSoc Directive. ${ }^{72}$ It then highlighted how the rationale of the fair compensation requirement is to compensate for the harm suffered by rightholders as a result of the reproduction of their works without their authorisation. Not only are not publishers exclusive reproduction rightholders pursuant to Article 2 of the InfoSoc Directive, but they are not subject to any harm for the purpose of those exceptions. ${ }^{73}$ As such, they cannot be the beneficiaries of any fair compensation. ${ }^{74}$

The decision in Reprobel supports the view that the notion of 'rightholders' in the InfoSoc Directive is not generic, but is rather an umbrella term for the subjects indicated in Articles 2 to 4 of the directive. These, as a result, should be considered part of a closed catalogue. It thus appears that no rightholders other than those expressly indicated in the directive can be created. Extending the reasoning of Svensson and Reprobel to the present discussion, this means that, on the one hand, exclusive rights cannot be broadened - whether by means of copyright or neighbouring rights - beyond the scope of what relevant provisions in the InfoSoc Directive (Articles 2 to 4 ) encompass and, on the other hand, that the initial owners of such right are individual creators, not other subjects (including press publishers).

\footnotetext{
67 Ibid, [140].

${ }^{68}$ European Copyright Society (2015).

69 Ibid, 4.

70 See Question 1 at http://www.publishersright.eu/.

${ }^{71}$ Huss-Ekerhult (2015), 1.

72 Hewlett-Packard Belgium SPRL v Reprobel SCRL, cit, [47].

73 Ibid, [48].

74 Ibid, [49].
} 


\subsection{Barriers to the internal market}

A third, systemic, argument that weighs against the compatibility of national rights for press publishers with EU law comes from considerations relating to the goals that the EU legislature intended to achieve through the InfoSoc Directive. It appears that by adopting the InfoSoc Directive the EU has pre-empted any national initiatives that would result in differences in the scope of protection of copyright and neighbouring rights which are such as to raise (again) those barriers to the free movement of goods and services based on incorporating copyright works that the EU legislatures intended to remove. The doctrine of EU preemption is neighbouring to, although distinct from, the doctrine of EU supremacy. ${ }^{75} \mathrm{It}$ is somewhat codified in Article 2(2) of the Treaty on the Functioning of the European Union (TFEU). ${ }^{76}$ This provision stipulates that when the Treaties confer on the Union a competence shared with the Member States in a specific area (as is the case of intellectual property pursuant to Article 115 TFEU), the Union and the Member States may legislate and adopt legally binding acts in that area. However, the Member States shall exercise their competence to the extent that the Union has not exercised or has decided to cease to exercise its competence. ${ }^{77}$ Further to Member States' concerns re the pre-emptive impact of Article 2(2) TFEU, the Protocol on Shared Competence clarifies that pre-emption occurs to the extent that the EU has exercised its competence in a certain area. More specifically, the scope of the exercise of competence by the Union "only covers those elements governed by the Union act in question and therefore does not cover the whole area." 78

For the present discussion, it is key to consider again Recitals 6 and 7 in the preamble to the InfoSoc Directive. On the one hand, legislative intervention at the EU level was deemed necessary to avoid different national responses to technological challenges that might result in "significant differences in protection and thereby in restrictions on the free movement of services and products incorporating, or based on, intellectual property, leading to a refragmentation of the internal market and legislative inconsistency." 79 On the other hand, not only should national provisions on copyright and neighbouring rights which vary considerably from one Member State to another or which cause legal uncertainties hindering the smooth functioning of the internal market and the proper development of the information society in Europe be adjusted, but also "inconsistent national responses to the technological developments should be avoided", insofar as they would adversely affect the functioning of the internal market. ${ }^{80}$ With its forward-looking geist, the latter recital suggests that the preemptive force of the InfoSoc Directive applies to any national legal arrangements not considered at the time when the directive was adopted. It follows that, although the InfoSoc Directive entered into force at a time when certain issues and challenges were either just

\footnotetext{
${ }^{75}$ Schütze (2012), 364.

76 Treaty on the Functioning of the European Union (consolidated version 2012), OJ C 326, 47-200.

${ }^{77}$ Craig and de Búrca (2015), 84-85.

78 Ibid, Protocol (No 25) on the exercise of shared competence.

79 InfoSoc Directive, Recital 6.

80 lbid, Recital 7.
} 
present in nuce or not even foreseeable, the interpretation of relevant provisions therein should be expansive, as CJEU case law (especially in more recent times) suggests.

\section{Member States cannot create new neighbouring rights, but what about an EU-wide publishers' right?}

Prior to the decisions in Svensson and C More it might have been doubtful whether Member States would retain any freedom to legislate in respect of exclusive rights harmonised at the EU level, whether through initiatives in the area of copyright or neighbouring rights. It is however worth noting that relevant earlier CJEU jurisprudence already suggested that this could not be the case. ${ }^{81}$ Moreover, this conclusion is not contradicted by the CJEU decision in FAPL. ${ }^{82}$ This was a reference for a preliminary ruling from the High Court of England and Wales, seeking clarification on a number of issues, including whether copyright protection could vest in football matches as such. The Court answered in the negative, on grounds that this subject-matter cannot be classified as a 'work', 83 lacking the required degree of originality. ${ }^{84}$ Moreover, according to the Court protection of such events under EU law is not available "on any other basis in the field of intellectual property". ${ }^{85}$ The CJEU conceded that sporting events as such have a unique and, to that extent, original character which can transform them into subject-matter that is worthy of protection comparable to the protection of works, and that protection can be granted, where appropriate, by the various domestic legal orders. ${ }^{86}$ However, in its decision the CJEU did not say that at the national level such protection could fall within the scope of intellectual property.

From Svensson and C More it now follows that: (1) in relation to copyright, the right of communication to the public cannot be extended to cover acts other than those mentioned by the InfoSoc Directive; and (2) in relation to neighbouring rights, Member States may broaden the categories of acts of communication to the public beyond what is indicated at Article 8 of the Rental and Lending Rights Directive. However, it appears that - also by analogy with the Reprobel decision - the freedom of Member States in the area of neighbouring rights does not go as far as to suggest that Member States also have the freedom to create new categories of rightholders in respect of neighbouring rights. Holding otherwise would mean defeating the harmonising efforts of the EU and contributing to the re-fragmentation of the internal market. It follows from the foregoing that Member States do not have the power to create new neighbouring rights, including neighbouring rights for

\footnotetext{
81 In relation to exclusive rights, see eg Martin Luksan v Petrus van der Let, C-277/10, EU:C:2012:65, particularly [64]; Football Dataco Ltd and Others v Yahoo! UK Ltd and Others, C-604/10, EU:C:2012:115, particularly [52] (both discussed further in Rosati (2014), 589-590).

82 Football Association Premier League Ltd and Others v QC Leisure and Others, C-403/08), and Karen Murphy v Media Protection Services Ltd, C-429/08, EU:C:2011:631.

$83 \mathrm{lbid},[96]$.

84 Ibid, [97]-[98].

85 Ibid, [99].

86 Ibid, [100].
} 
press publishers over their news content. This strengthens the conclusions of commentators who have argued for the unenforceability of German and Spanish rights for press publishers on procedural grounds, ie lack of notification to the EU Commission. ${ }^{87}$

\subsection{The current EU debate}

In 2015 the EU Commission released its Digital Single Market Strategy ${ }^{88}$ (DSMS), in which it presented future steps towards the realisation of a connected digital single market to generate additional growth in Europe in the course of the mandate of the present Commission, including "creating hundreds of thousands of new jobs, notably for younger jobseekers, and a vibrant knowledge-based society." 89 The DSMS intends to tackle a number of areas (including ecommerce, telecoms, cross-border sales, interoperability and standardisation, copyright and intellectual property enforcement) and is rooted within three main pillars: better access for consumers and businesses to online goods and services across Europe; creating the right conditions for digital networks and services to flourish; and maximising the growth potential of our European digital economy. ${ }^{90}$

As a further follow-up to its DSMS, in late 2015 the Commission issued a Communication in which it outlined possible future initiatives in the area of copyright. ${ }^{91}$ In line with the position that the EU Commissioner for Digital Economy and Society, Günther Oettinger, expressed in an interview with The Wall Street Journal shortly after its appointment ${ }^{92}$, among other things the Communication indicates that the Commission "will ... consider whether any action specific to news aggregators is needed, including intervening on rights." ${ }^{13}$ As further explained in the relevant factsheet accompanying the Communication,

"The Commission has no plan to tax hyperlinks. We have no intention to ask people to pay for copyright when they simply share a hyperlink to content protected by copyright. Europeans share and post hyperlinks every day and they should remain free to do so.

The Commission will look at the activities of different types of intermediaries in relation to copyright-protected content. This is a different issue.

\footnotetext{
${ }^{87}$ Vesterdorf (2015), 265-267.

${ }^{88}$ Communication from the Commission to the European Parliament, the Council, the European Economic and Social Committee and the Committee of the Regions, A digital single market strategy for Europe, $\operatorname{COM(2015)~}$ 192 final.

89 Ibid, 2.

90 lbid, 3-4.

${ }^{91}$ European Commission, Communication from the Commission to the European Parliament, the Council, the European Economic and Social Committee and the Committee of the Regions, Towards a modern, more European copyright framework, $\operatorname{COM}(2015) 626$ final.

92 Gummer and Robinson (30 October 2014).

93 Ibid, 10.
} 
News aggregators, for example, are not only using hyperlinks but also extracts of articles and may gain revenue doing so.

Different solutions neighbouring to news aggregators, both legislative and market-led, are being tested at national level. We are closely looking into them and are analysing whether they deliver on their objectives." 94

In 2016 the EU Commission launched a public consultation (that run between 23 March and 15 June 2016), seeking stakeholders' input as regards - among other things - the role of publishers in the copyright value chain. ${ }^{95}$ More specifically, through this public consultation the Commission intends to gather views as to whether publishers - newspapers, magazines, books or scientific journals - are facing problems in the digital environment as a result of the current copyright legal framework. This is notably with regard to their ability to licence and be paid for online uses of their content. Overall the Commission wishes to assess the impact that a possible change in EU law to grant publishers a new neighbouring right would have on them, on the whole publishing sector, on consumers/citizens and creative industries. The Commission also intends to gather views as to whether the need (or not) for intervention is different in the press publishing sector as compared to the book/scientific publishing sectors. In doing so, the Commission wishes to ensure the coherence of any possible intervention with other EU policies and in particular its policy on open access to scientific publications. ${ }^{96} \mathrm{As}$ such, the Commission appears open not only to the introduction of a neighbouring right for press publishers, but rather a right extended to publishers in some other sectors.

Shortly prior to the release of the Communication, a group of press publishers sent an open letter to the EU Commission, calling against the introduction of a press publishers' right at the EU level. ${ }^{97}$ Following the launch of the public consultation, diverging views regarding the merits of an EU-wide publishers' right have been advanced.

One the one hand a group of umbrella organisations in the European publishing sector ${ }^{98}$ has linked the need for an EU-wide publishers' right to the possibility of remaining competitive and independently financed in Europe's digital single market. The alleged current lack of clarity in this area would benefit those that would freeride on the press publishers investment. It is advocated "to include publishers into the catalogue of rightholders in EU copyright law allowing protection for the published edition, covering: reproduction right;

\footnotetext{
94 European Commission - Fact sheet, Making EU copyright rules fit for the digital age - questions \& answers ( 9 December 2015), available at http://europa.eu/rapid/press-release_MEMO-15-6262_en.htm.

95 European Commission, Public consultation on the role of publishers in the copyright value chain and on the 'panorama exception' (23 March 2016 - 15 June 2016), available at https://ec.europa.eu/digital-singlemarket/en/news/public-consultation-role-publishers-copyright-value-chain-and-panorama-exception.

96 Ibid.

97 Boyd (11 December 2015).

98 These are the European Publishers Council (www.epceurope.eu), the European Newspapers Publishers Association (www.enpa.eu), the European Magazine Media Association (www.magazinemedia.eu), and News Media Europe (www.newsmediaeurope.eu): see http://www.publishersright.eu/.
} 
right of communication and making available to the public; distribution right" ${ }^{99}$ The need for such right has seemingly stemmed from the challenges brought about by digitisation of content and distribution channels:

"When the InfoSoc Directive was proposed at the end of the 1990s, publishers were still for the most part offering only printed products and not yet subject to the mass reproduction and communication to the public that is the reality of today's digital landscape. The licensing situation was far less complex and the assignment of rights by various contributors to the publisher was more straightforward. Media diversity is a basic tenet of the European Union's Charter of Fundamental Rights. It is cherished as a citizen's right and continues to command respect through the role that the independent media play in our democratic Europe. But it comes at a cost, and with responsibilities." 100

On the other hand, academics like Hugenholtz have highlighted how, while the case for neighbouring rights for performers has always been strong (performing artists are excluded from the domain of authors' rights even though performing a work of authorship is usually a creative act),

"the same has never been true for the other three categories of neighbouring right holders. The main argument here is that such rights 'incentivize' and reward investment in producing phonograms (i.e. sound recordings), broadcasts or films, but the economics of this rationale remain largely unproven. ... [T] he best argument one can make for giving these industries their own IP rights is, here too, the absence of copyright protection. But this argument is very weak in light of actual contractual practices in these sectors." 101

With regard to the creation of an EU-wide right for publishers - whether in the press sector or also other sectors - it is submitted that this cannot be done without amending the InfoSoc Directive and Rental and Lending Rights Directive. Such amendments should be aimed at including relevant publishers - whether just in the press sector or also other sectors - among the categories of relevant rightholders in both directives. This inclusion would not be just necessary to allow the creation of a new neighbouring right at the EU level but also (further to the CMore decision) to allow Member States to possibly alter (ie broaden) its scope at the national level by allowing for the inclusion of acts other than those harmonised in the InfoSoc Directive and Rental and Lending Rights Directive.

\subsection{Is there a right of quotation? Yes but the quotation must come with comments or criticism}

A question that may arise is whether the introduction of such new, EU-wide, neighbouring right would be compatible with international copyright instruments. In her paper on the Spanish solution, Xalabarder argued that such initiative (at that time the relevant bill was still

\footnotetext{
99 Ibid, Question 2.

100 Ibid, Question 3.

101 Hugenholtz (14 April 2016).
} 
at the draft stage) would be contrary to Article 10(1) of the Berne Convention. ${ }^{102}$ The Computer \& Communications Industry Association (CCIA), ie an international membership organisation for a wide range of companies in the computer, Internet, information technology, and telecommunications industries, advanced the same arguments in its 2015 White Paper on Ancillary Copyright. ${ }^{103}$

Article 10(1) of the Berne Convention generously ${ }^{104}$ states that:

"It shall be permissible to make quotations from a work which has already been lawfully made available to the public, provided that their making is compatible with fair practice, and their extent does not exceed that justified by the purpose, including quotations from newspaper articles and periodicals in the form of press summaries." (emphasis added)

As recalled above, by adopting the InfoSoc Directive the EU intended to implement into the EU legal order the WIPO Internet Treaties. The WIPO Copyright Treaty requires compliance with Articles 1 to 21 of the Berne Convention.

Article 5 of the InfoSoc Directive contains an exhaustive list of exceptions and limitations that, save for the mandatory exception for temporary acts of reproduction in Article 5(1), Member States are free to transpose or not into their own legal systems. Article 5(3)(d) allows Member States to introduce into their own legal systems an exception or limitation to the rights of reproduction, communication/making available to the public and distribution to allow "quotations for purposes such as criticism or review, provided that they relate to a work or other subject-matter which has already been lawfully made available to the public, that, unless this turns out to be impossible, the source, including the author's name, is indicated, and that their use is in accordance with fair practice, and to the extent required by the specific purpose".

By using the modal verb 'shall' Xalabarder has argued - similarly to other commentators ${ }^{105}$ that Article 10(1) imposes on members of the Berne Union an obligation to introduce a quotation exception. Accordingly, the fact that Article 5(3)(d) "failed to formally address the mandatory nature of the quotation limitation, does neither affect nor alter the obligation of Spain and the EU to enforce the scope of uses exempted under Art.10(1)" of the Berne Convention. ${ }^{106}$

This position may be criticised for three main reasons.

\footnotetext{
102 Xalabarder (2014).

103 Computer and Communications Industry Association (2015).

104 See Ricketson (1999), 64, who speaks of "reasonably generous boundaries" in relation to the scope of Article 10(1) of the Berne Convention.

105 See, eg, Cohen Jeroham (2005), 360; Lewinski (2008), §5.163; Goldstein and Hugenholtz (2013), 391.

106 Xalabarder (2014), 2.
} 
First, by adopting the InfoSoc Directive the EU deprived Member States of their competence to implement the relevant provisions of the Berne Convention. A such, it would appear that Spain - as any other Member State - cannot give effect to Article 10(1) of the Berne Convention without also complying with the InfoSoc Directive and its Article 5. This conclusion is in line with both the literal wording of the InfoSoc Directive and CJEU case law, notably the 2012 decision in Luksan. ${ }^{107}$ In this reference for a preliminary ruling the Court considered whether an Austrian law that provided that all exclusive exploitation rights in a film vested in its producer and not also its principal director (as is instead the case under EU copyright) would be compatible with EU law. The Austrian Government had relied on Article 14bis(a) of the Berne Convention to advance the proposition that copyright ownership in a cinematographic work is a matter for legislation in the country where protection is sought. The CJEU however answered in the negative, and held that:

"In providing that the principal director of a cinematographic work is to be considered its author or one of the authors, the European Union legislature exercised the competence of the European Union in the field of intellectual property. In those circumstances, the Member States are no longer competent to adopt provisions compromising that European Union legislature. Accordingly, they can no longer rely on the power granted by Article 14bis of the Berne Convention."108

Secondly, it is not uncontroversial that Article 10(1) of the Berne Convention actually imposes the adoption of a quotation exception. It is true that this provision does not explicitly leave the determination of exceptions and limitations to the legislators of the Berne Union countries and the French version of the Convention employs the phrase "sont licites" ('are permitted') in lieu of "it shall be permissible". ${ }^{109}$ However, it is also possible to argue - on the basis of Article 19, 20 and 5(1) of the Berne Convention - that individual signatory countries (with the exception of the EU, where individual Member States have been deprived of their capacity to transpose directly the relevant provisions in the Berne Convention) are allowed to grant greater protection for copyright and that it is not obligatory to provide for limitations for quotations. ${ }^{110}$ Even by considering Article 10(1) of the Berne Convention as imposing the adoption of exceptions or limitations to permit quotations, national legislatures (including EU legislature) are free to prescribe the relevant conditions for their exercise. ${ }^{111}$

Thirdly, it may be questionable whether the display of links to and snippets of news content without any commentary may be considered as a quotation within Article 10(1) of the Berne Convention and Article 5(3)(d) of the InfoSoc Directive. ${ }^{112}$ In its decision in Painer, the CJEU clarified - among other things - the scope of the latter. This was a reference for a preliminary

\footnotetext{
107 Martin Luksan v Petrus van der Let, cit.

108 Ibid, [64].

109 Lewinski (2008), §5.163.

${ }^{110}$ Ficsor (2002), §5.11.

111 Goldstein and Hugenholtz (2013), 392.

112 In the same sense, see Lewinski (2010), §11.5.58: “Making a 'quotation' implies the requirement of using a part of another person's work or even, where excerpting is not possible, an entire work (such as a photograph or short poem), for the purpose of illustrating or proving a proposition neighbouring to the quoted work".
} 
ruling from the Vienna Commercial Court (Austria) made in the context of proceedings between freelance photographer Eva-Maria Painer and a number of German and Austrian press publishers over unauthorised publication of a number of photographs - as well as a photo-fit - that the claimant had taken of Natascha Kampusch prior to her abduction by Wolfgang Priklopil. The Vienna Commercial Court sought guidance from the CJEU on a number of issues, including the conditions of applicability of Article 5(3)(d) of the InfoSoc Directive.

In its analysis the CJEU confirmed the optional nature of the exception or limitation in Article $5(3)(d)$ of the InfoSoc Directive ${ }^{113}$, whose material scope is comparable to that of Article $10(1)$ of the Berne Convention. ${ }^{114}$ Article $5(3)(d)$ is intended to strike a fair balance between the right to freedom of expression of users of a work or other protected subject-matter and exclusive rights. ${ }^{115}$ It does so by favouring the exercise of the users' right to freedom of expression over the interest of the author in being able to prevent the reproduction of extracts from his work which has already been lawfully made available to the public, whilst ensuring that the author has the right, in principle, to have his name indicated. ${ }^{116}$

The Court explained that Article 5(3)(d) intends to "to preclude the exclusive right of reproduction conferred on authors from preventing the publication, by means of quotation accompanied by comments or criticism, of extracts from a work already available to the public." 117 The CJEU also held that, contrary to the Italian Government's submission, "the part of the sentence 'provided that they relate to a work or other subject-matter which has already been lawfully made available to the public' in Article 5(3)(d) refers, unambiguously, to the work or other protected subject-matter quoted and not to the subject-matter in which the quotation is made." ${ }^{118}$ It follows that whether the quotation is made as part of a work protected by copyright or, on the other hand, as part of a subject-matter not protected by copyright, is irrelevant. ${ }^{119}$ The CJEU thus clarified that, contrary to certain national arrangements (eg France ${ }^{120}$ ), a quotation can be self-standing, ie not necessarily incorporated into another copyright work. However, the Court also indicated that the quotation at issue has to be accompanied by comments or criticism. The latter requirement may be read in light of the condition within Article 10(1) of the Berne Convention that the quotation must be "justified by the purpose", and also the three-step test in Article 5(5) of the InfoSoc Directive. However, it is worth observing that there is no specific requirement that the quotation at

\footnotetext{
${ }^{113}$ Eva-Maria Painer v Standard VerlagsGmbH and Others, cit, [119].

114 Ibid, [127].

115 Ibid, [134].

116 Ibid, [135].

117 Ibid, [120] (emphasis added).

118 Ibid, [131].

119 lbid, [136].

${ }^{120}$ Article L-122-5(3)(a) of the Code de la propriété intellectuelle states that quotations are allowed insofar as they clearly indicate the name of the author and the source, and are justified for by the critical, polemic, educational, scientific or information of the work in which they are incorporated. According to Benabou (2012), 148, the CJEU decision in Painer has de facto abolished the rule that a quotation must be attached to another work or subject-matter. In the same sense, see Derclaye (2014), 718.
} 
hand is accompanied by comments or criticism in the wording of Article 5(3)(d) of the directive. Although Painer remains an important case, it is possible to question the appropriateness of CJEU's approach there, also in light of later decisions. For instance, in Deckmyn the Court had been asked to clarify the notion of 'parody' within Article 5(3)(k) of the InfoSoc Directive. Among other things in its 2014 decision the CJEU held that a 'parody' has just two essential characteristics: first, to evoke an existing work while being noticeably different from it and, secondly, to constitute an expression of humour or mockery. ${ }^{121}$ There are no other requirements. In particular, unlike what AG Cruz Villalón held in his Opinion ${ }^{122}$, a parody does not have to display an original character of its own. ${ }^{123}$ This is because such from the wording of Article 5(3)(k) of the InfoSoc Directive it is not "apparent" that a parody should satisfy further conditions. ${ }^{124}$

This said, in light of the Painer requirement that the reproduction (and possible subsequent communication/making available to the public and distribution) of a third-party work can qualify as quotation if the extract in question is accompanied by comments or criticism, it may be doubtful whether - should a neighbouring rights for publishers be adopted at the EU level - the display of links and extracts from newspaper articles without any form of commentary would be in any case eligible for protection under Article 10(1) of the Berne Convention, as incorporated into Article 5(3)(d) of the InfoSoc Directive and as interpreted by the CJEU.

To this one must also add that the InfoSoc Directive might be in breach of the Berne Convention for not having made the quotation exception or limitation mandatory for Member States to implement into their own legal systems. However, currently no Member States could be considered in breach of their obligations under EU law and - through the InfoSoc Directive's implementation into the EU legal order or the WIPO Internet Treaties international law for not envisaging a quotation exception under their own copyright laws.

\section{Conclusion}

The preceding discussion has highlighted how, on the one hand, national initiatives resulted in the adoption of rights for press publishers may be contrary to Member States' obligations under EU law. On the other hand, an EU-wide neighbouring right for publishers - whether in the press sector alone or also other sectors - may be adopted by amending relevant directives, ie the InfoSoc Directive and Rental and Lending Rights Directive.

The focus of this contribution has been limited to a legal analysis of the lawfulness and feasibility of creating new rights under the EU copyright acquis. It has decided not to address

\footnotetext{
121 Johan Deckmyn and Vrijheidsfonds VZW v Helena Vandersteen and Others, C-201/13, EU:C:2014:2132, [20].

122 Opinion of Advocate General Pedro Cruz Villalón in Johan Deckmyn and Vrijheidsfonds VZW $v$ Helena Vandersteen and Others, C-201/13, EU:C:2014:458, [57].

123 Johan Deckmyn and Vrijheidsfonds VZW v Helena Vandersteen and Others, cit, [21].

124 Ibid.
} 
the merits and desirability as such of introducing such new rights. This would entail a comprehensive and more general discussion of what rationale underlies copyright and neighbouring rights protection. In this sense the question that remains open is whether, provided that new rights can be created (at least the EU level), copyright - and neighbouring policy and legislative action at the EU level - should not reward creativity and investment as such, but rather remedy to the economic losses that technological evolution has brought about in sectors where relevant business models have not always been able to adapt and evolve as rapidly as the former.

More general considerations relating to the possible chilling effects of including linking within the scope of protection (whether of copyright or new neighbouring rights) could be also raised. In his recent Opinion in GS Media, AG Wathelet argued that linking should not fall within Article 3(1) of the InfoSoc Directive at all. He stressed how:

"any other interpretation ... would significantly impair the functioning of the Internet and undermine one of the main objectives of Directive 2001/29, namely the development of the information society in Europe. Such an interpretation could also distort the 'fair balance of rights and interests between the different categories of rightholders, as well as between the different categories of rightholders and users of protected subject-matter." 125

125 Opinion of Advocate General Melchior Wathelet in GS Media BV v Sanoma Media Netherlands BV, Playboy Enterprises International Inc and Britt Geertruida Dekker, C-160/15, EU:C:2016:221, [77]. 


\section{References}

- $\quad$ ANSA (7 June 206), 'FIEG-Google deal to boost media sector', available at http://www.ansa.it/english/news/politics/2016/06/07/fieg-google-deal-to-boost-media-sector2_f68fd7ae-7002-43bf-97ad-08088724fa4b.html

- Barabash I (2013), 'Ancillary copyright for publishers: the end of search engines and news aggregators in Germany?' 35(5) EIPR 243

- Barthel M (29 April 2015), Newspapers: fact sheet - State of the news media 2015, available at http://www.journalism.org/2015/04/29/newspapers-fact-sheet/ (accessed 20 April 2016)

- Benabou V (2012), 'Retour sur dix ans de jurisprudence de la Cour de Justice de I'Union Européenne en matière de propriété littéraire et artistique' 43 Propriétés Intellectuelles 140

- Boyd J (11 December 2015), 'Ancillary copyright: group of press publishers write letter to the European Commission' International Federation of Reproduction Rights Organisations, available at http://ifrro.org/content/ancillary-copyright-group-press-publishers-write-letter-european-commission (accessed 20 April 2016)

- Bundeskartellamt (9 September 2015), 'Bundeskartellamt takes decision in ancillary copyright dispute', available at http://www.bundeskartellamt.de/SharedDocs/Meldung/EN/Pressemitteilungen/2015/09_09_2015_VG _Media_Google.html?nn=3591568 (accessed 20 April 2016).

- Calin M, Dellarocas C, Palme E and Sutanto J (2013), Attention allocation in information-rich environments: the case of news aggregators, Boston U School of Management Research Paper No 2013-4, available at http://papers.ssrn.com/sol3/papers.cfm?abstract_id=2225359 (accessed 20 April 2016)

- Chiou L and Tucker C (2015), Content aggregation by platforms: the case of news media, NBER Working Paper No 21404, available at http://www.nber.org/papers/w21404.pdf (accessed 20 April 2016)

- Cohen Jeroham H (2005), 'Restrictions on copyright and their abuse' 27(10) EIPR 359

- Comisión Nacional de los Mercados y la Competencia (16 May 2014) (CNMC), Pro/Cnmc/0002/14 Propuesta Referente A La Modificación Del Artículo 32.2 Del Proyecto De Ley Que Modifica El Texto Refundido De La Ley De Propiedad Intelectual

- Computer and Communications Industry Association (2015), CCIA White Paper - Understanding 'ancillary copyright' in the global intellectual property environment (2015), available at http://cdn.ccianet.org/wp-content/uploads/2015/02/CCIA-Understanding-Ancillary-Copyright.pdf (accessed 20 April 2016)

- Craig P and de Búrca G (2015), EU law - Text, cases and materials, $6^{\text {th }}$ edn

- Derclaye E (2014), 'The Court of Justice copyright case law: quo vadis?' 36(11) EIPR 716

- European Copyright Society (2015), Opinion on the reference to the CJEU in Case C-572/13 HewlettPackard Belgium SPRL v. Reprobel SCRL, available at https://europeancopyrightsocietydotorg.files.wordpress.com/2015/12/opinion-in-case-c572_13-hpbelgium-reprobel-2015.pdf (accessed 20 April 2016)

- Ficsor M (2002), The law of copyright and the Internet: the 1996 WIPO Treaties, their interpretation and implementation

- Geerts T (12 December 2012), 'Partnering with Belgian news publishers' Google Europe Blog, available at http://googlepolicyeurope.blogspot.co.uk/2012/12/partnering-with-belgian-news-publishers.html (accessed 20 April 2016)

- Gingras R (11 December 2014), 'An update on Google News in Spain' Google Europe Blog, available at http://googlepolicyeurope.blogspot.co.uk/2014/12/an-update-on-google-news-in-spain.html (accessed 20 April 2016)

- Goldstein P and Hugenholtz B (2013), International copyright. Principles, law, and practice, $3^{\text {rd }}$ edn

- Gummer C and Robinson F (30 October 2014), 'New EU digital chief floats tough anti-Google regulations' The Wall Street Journal, available at http://blogs.wsj.com/digits/2014/10/30/new-eudigital-chief-floats-tough-anti-google-regulations/ (accessed 20 April 2016)

- Hugenholtz B (14 April 2016), 'Say nay to the neighbouring right!' Kluwer Copyright Blog, available at http://kluwercopyrightblog.com/2016/04/14/say-nay-to-the-neighbouring-right/ (accessed 20 April 2016) 
- Hugenholtz PB (2000), 'Why the Copyright Directive is unimportant, and possibly invalid' 22(11) EIPR 499, 500

- Huss-Ekerhult A (2015), IFRRO Comments regarding the European Copyright Society's Opinion on Case C-572/13, Hewlett-Packard Belgium v. Reprobel, available at

http://ifrro.org/sites/default/files/ifrro_response_to_european_copyright_society_opinion_29sept201 5.pdf (accessed 20 April 2016)

- Lardinois F (21 June 2013), 'Google makes Google News in Germany opt-in only to avoid paying fees under new copyright law' TechCrunch, available at http://techcrunch.com/2013/06/21/google-makesgoogle-news-in-germany-opt-in-only-to-avoid-paying-fees-under-new-copyright-law/ (accessed 20 April 2016)

- La Stampa (7 June 2016), 'Fieg e Google firmano un accordo per collaborare', La Stampa, available at http://www.lastampa.it/2016/06/07/economia/fieg-e-google-firmano-un-accordo-per-collaborare6xl7WBCgb6TPCEFKcUfwLK/pagina.html

- Lewinski S (2008), International copyright law and policy

- Lewinski S (2010), 'Information Society Directive', in Lewinski S and Walter MM (eds), European copyright law - A commentary

- Lewinski S (2010), 'Rental and Lending Rights Directive', in

- Madsen P and Andsager J (2012), Aggregating agendas: online news aggregators as agenda setters, paper presented to the Association for Education in Journalism and mass communication annual conference, available at http://www.mapor.org/confdocs/absandpaps/2011/2011_papers/1a1Madsen.pdf (accessed 20 April 2016)

- Price G (2015), Opportunities and challenges for journalism in the digital age: Asian and European perspectives Chatham House - The Royal Institute of International Affairs, available at http://www.asef.org/images/docs/Final\%20Chatham\%20House\%20Monograph-ERT7-20150825.pdf (accessed 20 April 2016)

- Rabenstein G (21 June 2013), 'Google News bleibt offene Plattform für alle deutschen Verlage' Der offizielle Google Produkt-Blog, available at http://google-produkte.blogspot.co.uk/2013/06/googlenews-bleibt-offene-plattform-fuer-verlage.html (accessed 20 April 2016)

- Ricketson S (1999), 'The boundaries of copyright: its proper limitations and exceptions: international conventions and treaties' 1 IPQ 56

- Rosati E (24 November 2012), 'French minister of culture speaks of Google, Amazon and Loi Hadopi' The 1709 Blog, available at http://the1709blog.blogspot.co.uk/2012/11/french-minister-of-culturespeaks-of.html (accessed 20 April 2016)

- Rosati E (2014), 'Copyright in the EU: in search of (in)flexibilities' 9(7) JIPLP 585

- Scalzini S (2015), 'Is there free-riding? A comparative analysis of the problem of protecting publishing materials in Europe' 10(6) JIPLP 454, 461-463

- Schmidt E (1 February 2013), 'Google creates €60m Digital Publishing Innovation Fund to support transformative French digital publishing initiatives' Google Official Blog, available at https://googleblog.blogspot.co.uk/2013/02/google-creates-60m-digital-publishing.html (accessed 20 April 2016)

- Schütze R (2012), European constitutional law

- Vesterdorf B (2015), 'The effect of failure to notify the Spanish and German ancillary copyright laws' 37(5) EIPR 263

- Xalabarder R (2014), 'The remunerated statutory limitation for news aggregation and search engines proposed by the Spanish Government - its compliance with international and EU law' IN3 Working Paper Series, available at http://papers.ssrn.com/sol3/papers.cfm?abstract_id=2504596\&download=yes (accessed 20 April 2016) 